\title{
Antibacterial Effect of Hydroalcoholic Extracts of Herb- al Plants Against Some Hospital-acquired Infections
}

\author{
Hassan Habibi ${ }^{* *}$ (D), Noorsaadat Saajedi², Najmeh Ghahtan ${ }^{3}$ (D), Saajedeh Habibi ${ }^{4}$
}

1. Department of Animal Sciences, Agricultural and Naturalresources, Persian Gulf University, Bushehr, Iran.

2. Department of Obstetrics and Gynecology, School of Medicine, Iran University of Medical Sciences, Tehran, Iran.

3. Department of Student of Horticultural Sciences, School of Agriculture and Natural Resources, Persian Gulf University, Bushehr, Iran.

4. School of Medicine, Yazd Shahid Sadoughi University of Medical Sciences, Yazd, Iran.

\begin{tabular}{|l|l|}
\hline $\begin{array}{c}\text { Use your device toscan } \\
\text { and read the article online }\end{array}$ & $\begin{array}{l}\text { Crtation Habibi H, Saajedi N, Ghahtan N, Habibi S. Antibacterial Effect of Hydroalcoholic Extracts of Herbal Plants Against } \\
\text { Some Hospital-acquired Infections. Research in Molecular Medicine. 2020; 8(3):133-138. https://doi.org/10.32598/rmm.8.3.1 }\end{array}$ \\
dol'https://doi.org/10.32598/rmm.8.3.1
\end{tabular}

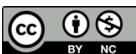

Article Type:

Research Article

Article info:

Received: 24 Apr 2020

Revised: 30 May 2020

Accepted: 24 Jun 2020

Keywords:

Lallemantia iberica,

Sinapis arvensis,

Hospital-acquired infection,

Antibacterial

\begin{abstract}
A B S T R A C T
Background: Due to increased bacterial resistance to common antibiotics, the tendency towards using herbal extracts is increasing. Plantago major L, Plantago ovata, Lallemantia iberica L, Sinapis arvensis L, and Ficus carica are widely used as herbal plants in traditional medicine. They were known to have a variety of therapeutic effects. The current study aimed to evaluate the antibacterial activity of hydroalcoholic extract of these herbs against some hospital-acquired infections.

Materials and Methods: Disk-diffusion antibiotic sensitivity testing, minimum inhibitory concentration, and minimum bactericidal concentration of hydroalcoholic extracts were applied to assess the antibacterial activity compared with tetracycline, as a control antibiotic.

Results: The results of this experiment showed that the L. iberica and S. arvensis extract had the greatest effect on Pseudomonas aeruginosa, Staphylococcus aureus, and Proteus vulgaris. All the tested medicinal plants had a high antibacterial effect on P. vulgaris, except P. ovata.

Conclusion: The results of this study show that the replacement of chemical drugs with herbal extract could be effective in the elimination of bacterial growth.
\end{abstract}

\section{Introduction}

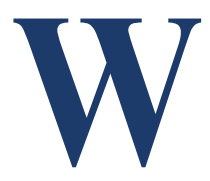

ound infection is a common and serious complication of surgical operations. It is the second most frequent nosocomial infection in hospitals. Although eradication of wound infections in surgeries seems impossible, decreasing the number of infection victims will result in significant benefits such as higher patient satisfaction and lower medical costs [1]. The bacterial agents, including Staphylococcus aureus, Pseudomonas aeruginosa, and Proteus vulgaris cause several human infections [2].

Staphylococcus aureus is one of the main causes of surgical wound infections in hospitalized patients and

\section{* Corresponding Author:}

Hassan Habibi, PhD.

Address: Department of Animal Sciences, Agricultural and Naturalresources, Persian Gulf University, Bushehr, Iran.

Phone: +98 (77) 34221462

E-mail: h.habibi@pgu.ac.ir 
medical device-related contaminations. S. aureus is predominantly colonized on the surface of the skin and mucosa, and can also survive in all tissues of the body [3, 4]. Pseudomonas aeruginosa is a multidrug-resistant pathogen, recognized early for its ubiquity, and its mechanism of advanced inherently antibiotic resistance [5]. Proteus vulgaris is one of the normal flora of the human digestive system that can cause urinary tract infection, especially in patients with a weak immune system [6].

The antibiotics are among the most common methods used to eliminate pathogenic bacteria and of great benefit in maintaining human health. However, the resistance of many pathogenic bacteria to these antibiotics is one of the biggest challenges facing humans let alone their adverse effects in humans' bodies [7, 8]. During the last several decades, natural products with antimicrobial effects have been investigated to eliminate the use of synthetic antibiotics which cause the resistance of microorganisms and can exhibit side effects on human health [9]. Aromatic plants are known for a very long time and they are used in phototherapy and food preservation [10]. Plant extracts are the potentially useful sources of antimicrobial compounds. Many studies have been conducted on the antimicrobial activities of plant compounds against many different types of microorganisms, including hospital-acquired infections [11].

Plantago ovata Forssk (Plantaginaceae family) is a winter annual plant [12]. The seeds of this plant contain 20\%-30\% mucilage, which produces D-xylosan, arabinose, D-galactose, and D-galacturonic acid by hydrolysis process [13]. Plantago ovata can reduce the level of cholesterol in the blood, anti-diarrheal effect that can set blood sugar [14]. Its effect has been determined on various bacteria, including Staphylococcus aureus, Streptococcus pyogenes, and Bordetella bronchiseptica [12].

Plantago major is a perennial medicinal herb. It has been reported to cure numerous diseases from common cold to hepatitis, skin diseases, infectious diseases, fever, problems concerning the digestive organs, respiratory organs, reproduction, the circulation [15].

Lallemantia iberica L contains compounds such as $\beta$-cubebene, linalool, and spathulenol. Notably, this medicinal herb has a strong antioxidant effect [16].

The Ficus carica Linn leaves contain several active compounds such as flavonoids, tannins, sesquiterpenes, alkaloids, and saponins [17], which have antioxidant, anticancer, anti-inflammation, antiviral, and antibacterial activities [18]. Sinapis arvensis L, a genus of Brassicaceae, has a long history of use as condiments and as herbal medicines. In many developing countries, Sinapis species are used as food, fodder to livestock, and herb in folklore medicine [19]. The objective of the current study was to evaluate the antibacterial activity of hydroalcoholic extract of Plantago major L, Plantago ovata, Lallemantia iberica L, Sinapis arvensis L, and Ficus carica against Pseudomonas aeruginosa, Staphylococcus aureus, and Proteus vulgaris.

\section{Materials and Methods}

\section{Preparation of herbal samples}

The aerial parts of plants were collected from their natural habitat in Bushehr Province, Iran. The samples were dried out in a dry and dark environment (far from sunlight). Samples were also pulverized to obtain a powder. Noticed in the voucher that a specimen from each variety was deposited in the Herbarium of Agriculture and Natural Resources Faculty of Persian Gulf University (Bushehr, Iran).

\section{Extraction}

Hydroalcoholic extract (ethanol 70\%) was prepared by seed soaking for 48 hours at room temperature and then filtered with filter paper. The following oils were used: Plantago major L (P. major), Plantago ovata (P. ovata), Lallemantia iberica L (L. iberica), Sinapis arvensis L (S. arvensis) and Ficus carica (F. carica) [16]. Species and genus of plants were diagnosed by an expert in botany.

\section{Microorganisms}

Pseudomonas aeruginosa, Staphylococcus aureus, and Proteus vulgaris were used to study the antibacterial properties of plants. By morphocultural and biochemical characteristics, the isolated bacterial strains were identified. Gram staining and biochemical tests were done as per the guidelines of the Clinical and Laboratory Standards Institute [20]. A pure culture of the strains was maintained at $-20^{\circ} \mathrm{C}$ in brain heart infusion broth (Merck) containing 10\%-15\% glycerol, which was thawed before use. To prepare bacterial inocula, $0.1 \mathrm{~mL}$ of the thawed cultures were transferred to $10 \mathrm{~mL}$ of sterile Tryptic soy broth (TSB, Merck) and was incubated overnight at $37^{\circ} \mathrm{C}[12]$.

\section{Antimicrobial assay}

Agar gel disk diffusion test, minimum inhibitory concentration (MIC) and minimum bactericidal concentration (MBC) were used in this study. 


\section{Disk diffusion susceptibility}

Antibacterial susceptibility assay of Mueller-Hinton Broth (MHB, Merck) medium was used to grow the test isolates at $37^{\circ} \mathrm{C}$ for $22 \mathrm{~h}$. Final bacterial numbers were standardized to $1 \times 10^{6} \mathrm{CFU} / \mathrm{mL}$. A total of $0.1 \mathrm{~mL}$ of bacterial suspension was poured into each plate containing Mueller-Hinton Agar. The surface culture was prepared by sterile L shape pipet Pasteur and allowed to remain in contact for $1 \mathrm{~min}$. Thereafter, a 5\% concentration of each plant essential oils was prepared. The sterile filter paper disks (6-mm diameter) were placed on the cultures and $24 \mathrm{~h}$ after incubation at $37^{\circ} \mathrm{C}$, the zone diameter of inhibition (ZDI) was measured in $\mathrm{mm}$. To determine the sensitivity of each bacterial species tested, tetracycline was used as a positive control standard (three replications for each extract) [21].

\section{MIC and MBC}

For each extract and essential oil, a set of 9 sterile test tubes were used. The stock solutions $(500 \mathrm{mg} / \mathrm{mL})$ were further diluted in a 2-fold serial dilution to obtain the following concentrations of $250,125,62.5,31.25,15.625$, $7.8125,3.91,1.95$, and $0.98 \mathrm{mg} / \mathrm{mL}$. One test tube as a negative control and tetracycline as positive control were used. An aliquot of $1 \mathrm{~mL}$ of the bacterial suspension was inoculated into each tube. The negative control tubes were inoculated with the same quantity of extracts. Then the tubes were incubated for $24 \mathrm{~h}$ at $37^{\circ} \mathrm{C}$. Based on the MIC definition, the last tube with no turbidity was considered as MIC. To determine the MBC, the solution of the transparent tubes of the previous step was cultured in the TSA medium. A plate with no bacterial growth was considered as MBC (three replications for each extract) [21]. Pseudomo- nas aeruginosa ATCC 27853 and Staphylococcus aureus ATCC 25923 were used as the control strain in this test.

\section{Statistical analysis}

To determine the significant difference among the obtained results from zone inhibition assays, MIC and MBC average analyses were carried out in SPSS v. 16.0. The differences between any means were tested by the Duncan test and the results were considered significant when $\mathrm{P}<0.05$.

\section{Results}

\section{Antimicrobial activity of the tested extracts}

Results indicated that all five plants had high antibacterial effects on S. aureus. Also, P. aeruginosa was highly affected by L. iberica and S. arvensis. All the tested medicinal plants had a high antibacterial effect on P. vulgaris, except $P$. ovata (Table 1).

\section{MIC and MBC}

The MIC values of the hydroalcoholic extract of medicinal plants, at different concentrations ranging from $0.98 \mathrm{mg} / \mathrm{mL}$ to $250 \mathrm{mg} / \mathrm{mL}$, in comparison with the activity of tetracycline has been shown in Tables 2 and 3 .

\section{Discussion}

According to the previous studies, the ZDI values of $>15 \mathrm{~mm}, 10-15 \mathrm{~mm}$, and $<10 \mathrm{~mm}$ diameter are considered as high, medium, and low antibacterial effects of the essential oils or extracts, respectively [22].

Table 1. Inhibition zone (Mean \pm SD, $\mathrm{mm}$ ) results of hydroalcoholic extracts against some hospital-acquired infections

\begin{tabular}{cccc}
\hline & & Mean \pm SD & \\
\cline { 2 - 4 } Treatment & Pseudomonas Aeruginosa & Staphylococcus Aureus & Proteus Vulgaris \\
\hline Plantago major & $0.00 \pm 0.00^{\mathrm{c}}$ & $20.33 \pm 1.52^{\mathrm{c}}$ & $21.66 \pm 1.52^{\mathrm{c}}$ \\
\hline Plantago ovata & $0.00 \pm 0.00^{\mathrm{c}}$ & $13.33 \pm 0.57^{\mathrm{e}}$ & $0.00 \pm 0.00^{\mathrm{d}}$ \\
\hline Lallemantia iberica & $16.33 \pm 1.15^{\mathrm{b}}$ & $30.00 \pm 1.00^{\mathrm{b}}$ & $32.00 \pm 0.00^{\mathrm{b}}$ \\
\hline Sinapis arvensis & $16.00 \pm 1.00^{\mathrm{b}}$ & $30.33 \pm 0.57^{\mathrm{b}}$ & $35.00 \pm 1.00^{\mathrm{a}}$ \\
\hline Ficus carica & $0.00 \pm 0.00^{\mathrm{c}}$ & $15.16 \pm 0.28^{\mathrm{d}}$ & $20.33 \pm 1.52^{\mathrm{c}}$ \\
Tetracycline & $36.00 \pm 0.00^{\mathrm{a}}$ & $39.33 \pm 1.15^{\mathrm{a}}$ & $35.16 \pm 0.28^{\mathrm{a}}$ \\
\hline
\end{tabular}

Means within same column with different superscripts differ $(\mathrm{P}<0.05)$. Non-similar alphabets in each column .indicate a significant difference between treatments 
Table 2. MIC $(\mathrm{mg} / \mathrm{mL})$ results of hydroalcoholic extracts against some hospital-acquired infection-causing bacteria

\begin{tabular}{cccc}
\hline Treatment & Pseudomonas Aeruginosa & Staphylococcus Aureus & Proteus Vulgaris \\
\hline Plantago major & No & 31.22 & 62.5 \\
\hline Plantago ovata & No & 62.5 & No \\
\hline Lallemantia iberica & 62.5 & 15.62 & 31.22 \\
\hline Sinapis arvensis & 31.22 & 7.81 & 3.91 \\
\hline Ficus carica & No & 125 & 7.81 \\
\hline Tetracycline & 3.91 & 7.81 & \\
\hline NO: No effect; $\mathrm{P}<0.05$ & & & 0.25 \\
\hline
\end{tabular}

Table 3. $\mathrm{MBC}(\mathrm{mg} / \mathrm{mL})$ results of hydroalcoholic extracts against some hospital-acquired infection-causing bacteria

\begin{tabular}{|cccc}
\hline Treatment & Pseudomonas Aeruginosa & Staphylococcus Aureus & Proteus Vulgaris \\
\hline Plantago major & No & 125 & 250 \\
\hline Plantago ovata & No & 62.5 & No \\
\hline Lallemantia iberica & 125 & 31.22 & 62.5 \\
\hline Sinapis arvensis & 62.5 & 7.81 & 15.62 \\
\hline Ficus carica & No & 250 & 125 \\
\hline Tetracycline & 15.62 & 7.81 & 15.62 \\
\hline NO: No effect; $P \leq 0.05$ & & & PRm
\end{tabular}

Results of this experiment showed that the seed extract of L. iberica and S. arvensis have a high antibacterial effect against P. aeruginosa, S. aureus, and P. vulgaris. In the present study, S. arvensis hydroalcoholic extract had the strongest antibacterial effect against P. vulgaris (35 mm inhibition zone). Oil seeds have been used for making soap, cooking, and lubricating, and the whole plant used as green fodder [23]. The antibacterial effect of L. iberica seed extracts has studied against Pseudomonas aeruginosa (18.3 $\pm 6.5 \mathrm{~mm}$ inhibition zone), Bacillus subtilis (16.6 $\pm 4.1 \mathrm{~mm}$ inhibition zone), Bacillus cereus (11.3 $\pm 2.5 \mathrm{~mm}$ inhibition zone), Bacillus sphaericus (15.3 $\pm 3 \mathrm{~mm}$ inhibition zone), Escherichia coli O157 (9.6 $\pm 1.5 \mathrm{~mm}$ inhibition zone), Salmonella liatica, and Salmonella typhimurium ATCC3598 (14.6 $\pm 2.3 \mathrm{~mm}$ inhibition zone) and it had a significant effect on all the mentioned bacteria [16]. L. iberica produced many secondary metabolites such as phenolic acids, flavonoids, tannins, triterpene, mucilage, and oil [24]. The secondary metabolites such as linalool and thymol exterminate the bacterial membrane, cause liposaccharides leakage, and increase the cytoplasmic membrane permeability to ATP. Eventually, the exit of ATP leads to the loss of cellular energy storage and cell death $[16,25]$.
Ficus carica exhibited high inhibition zones of 15.16 and $20.33 \mathrm{~mm}$ on $\mathrm{S}$. aureus and P. vulgaris. The MIC value for the F. carica was $125 \mathrm{mg} / \mathrm{mL}$ against $\mathrm{S}$. aureus and $\mathrm{P}$. vulgaris. The $\mathrm{MBC}$ values for the $\mathrm{F}$. carica were $250 \mathrm{mg} / \mathrm{mL}$ against $\mathrm{S}$. aureus and $125 \mathrm{mg} / \mathrm{mL}$ against $\mathrm{P}$. vulgaris. The major components of $\mathrm{F}$. carica were arabinose, $\beta$-amyrins, $\beta$-carotines, glycosides, $\beta$-setosterols, and xanthotoxo [26]. The obtained results indicate the therapeutic virtue of F. carica leaves as an antimicrobial agent against some microbial infection, such infection by methicillin-resistant $\mathrm{S}$. aureus which recognized as a global nosocomial problem [27]. Jung reported that the methanol extract from the leaves of F. carica exhibited a strong effect against Escherichia coli but weak effect against $\mathrm{S}$. aureus [28].

P. major contains biologically active compounds such as polysaccharides, lipids, caffeic acid derivatives, flavonoids, iridoid glycosides, alkaloids, and terpenoids [29]. This plant is an important medicinal plant with different pharmacological properties, including anti-inflammation, analgesic, wound healing, antipyretic, antitussive, anti-infective, anti-hemorrhagic, laxative, astringent, hemostatic activity and diuretic [30] to manage a wide 
range of diseases including constipation, coughs and wounds. The aim of this study is to review the traditional application, botanical characterization, pharmacological activities, phytochemistry effects and toxicity of Plantago major. In this review study, medicinal properties of Plantago major are collected from credible pharmacopeias, textbooks of traditional Persian medicine (TPM. In this experiment, P. major had a significant effect on $\mathrm{S}$. aureus. Also, P. vulgaris showed a significant difference from the control antibiotic. Mohammadsadeghi et al. reported that different extracts (hydroalcoholic extracts) of $P$. major leaves exhibit antibacterial activity against Pseudomonas aeruginosa, Klebsiella pneumonia, and Staphylococcus aureus [20].

Investigations showed that $P$. ovata can inhibit B. sphaericus (16 mm inhibition zone) and B. subtilis (14.6 $\mathrm{mm}$ inhibition zone) [16]. P. ovata showed less activity than P. major, L. iberica L, S. arvensis, and F. carica against all tested pathogenic bacteria. Studies showed that the extracts made from $P$. ovata had antibacterial activity against many bacteria such as S. aureus, Strep. pyogenes, and B. bronchiseptica [12]. Sharif et al. reported that the MIC of Plantago Psyllium against Staphylococcus aureus and Staphylococcus epidermidis were $20 \mathrm{~mm}$ and $18 \mathrm{~mm}$, respectively [31].

\section{Conclusion}

In conclusion, the seed extract of L. iberica and S. arvensis have a high antibacterial effect against $\mathrm{P}$. aeruginosa, S. aureus, and P. vulgaris. Our results support the use of these plants in traditional medicine and suggest that some of the plant essential oils possess compounds with good antibacterial properties that can be used as antimicrobial agents in the search for new drugs.

\section{Ethical Considerations}

Compliance with ethical guidelines

All ethical principles were considered in this article.

Funding

This research did not receive any specific grant from funding agencies in the public, commercial, or notforprofit sectors.

\section{Authors' contributions}

Financial support: Hassan Habibi, Noorsaadat Saajedi and Najmeh Ghahtan; Collection of data, statistical anal- ysis and drafting of the manuscript: Hassan Habibi, Najmeh Ghahtan; Writing - original draft: Hassan Habibi. Saajedeh Habibi

\section{Conflict of interest}

The authors declared no competing interests.

\section{Acknowledgements}

The authors are grateful to technicians of the Biotechnology Laboratory of Persian Gulf University for their valuable technical assistance.

\section{References}

[1] Rahmani Gohar M, Moslemi D, Kafshdouzan D. Antibacterial activity of origanum vulgare on staphylococcus aureus in a rat model of surgical wound infection. J Med Plants Stud. 2016; 15(57):19-24.

[2] Khan UA, Rahman H, Niaz Z, Qasim M, Khan J, Tayyaba Rehman B. Antibacterial activity of some medicinal plants against selected human pathogenic bacteria. Eur J Microbiol Immunol (Bp). 2013; 3(4):272-4. [DOI:10.1556/EuJMI.3.2013.4.6] [PMID] [PMCID]

[3] Wisal ME, Hamid MA, Hadia EA, Jalii IM, Ali AS. Coagulase gene polymorphism of Staphylococcus aureus strains isolated from human, animals and enviroment. Pak J Biol Sci. 2015; 8(2):278-80. [DOI:10.3923/pjbs.2005.278.280]

[4] Fournier B, Philpott DJ. Recognition of Staphylococcus aureus by the innate immune system. Clin Microbiol Rev. 2015 18(3): 521-40. [DOI:10.1128/CMR.18.3.521-540.2005] [PMID] [PMCID]

[5] Abkhoo J, Jahani S. Antibacterial Effects of Aqueous and Ethanolic Extracts of Medicinal Plants Against Pathogenic Strains. Int J Infect. 2017; 4(2):e42624. [DOI:10.5812/iji.42624]

[6] Gul N, Ozkorkmaz EG, Kelesoglu I, Ozluk A. An ultrastructural study, effects of Proteus vulgaris OX19 on the rabbit spleen cells. Micron. 2013; 44:133-6. [DOI:10.1016/j.micron.2012.05.010] [PMID]

[7] Al-Wazni W, Al-Qarraawi R, Jaber S. Antibacterial activity of Pomegranate molasses (alone and in combination with Ampicillin and Ciprofloxacin) on multidrug resistant Serratia marcescen. J Phys Conf Sci. 2018; 1032:1-7. [DOI:10.1088/1742-6596/1032/1/012071]

[8] Liu Q, Meng X, Li Y, Zhao CN, Tang GY, Li HB. Antibacterial and antifungal activities of spices. Int J Mol Sci. 2017:18(6):1283. [DOI:10.3390/ijms18061283] [PMID] [PMM CID]

[9] Mahato TM, Sharma K. Study of medicinal herbs and its antibacterial activity: A review. J Drug Deliv Ther. 2018; 8(5S):47-54. [DOI:10.22270/jddt.v8i5-s.1938] 
[10] Sahraei S, Mohkami Z, Golshani F, Javadian F, Saeidi S, Baigi GS. Antibacterial activity of five medicinal plant extracts against some human bacteria. Pelagia Res Libr: Eur J Exp Biol. 2014; 4(3):194-6.

[11] Ozkalp B, Sevgi F, Ozcan M, Ozcan MM. The antibacterial activity of essential oil of oregano (Origanum vulgare L.). J Food Agric Environ. 2010; 8(2):272-4. [DOI:10.1234/4.2010.1639.]

[12] Motamedi H, Darabpour E, Gholipour M, Seyyed Nejad SM. Antibacterial effect of ethanolic and methanolic extracts of Plantago ovata and oliveria decumbens endemic in Iran against some pathogenic bacteria. Int J Pharmacol. 2010; 6(2):117-22. [DOI:10.3923/ijp.2010.117.122]

[13] Singh S, Singh R, Kumar N, Kumar R. Wound healing activity of ethanolic extract of Plantago ovata (Ispaghula) seeds. J Appl Pharm Sci. 2011; 1(7):108-11.

[14] Thari VL, Battepati VKCB, Chinnari S, Adari AC, Saibaba N, Gopinadh R. Review on the characteristics and applications of psyllium (Plantago ovata). Int J Biotech Res. 2018; 1(1):31-41.

[15] Abd Razik BM, Hiba Hasan H, Murtadha MK. The study of antibacterial activity of plantago major and ceratonia siliqua. Iraqi Postgrad Med J. 2012; 11(1):130-5.

[16] Karami L, Ghahtan N, Habibi H. Antibacterial effect of plantago ovata and lallemantia iberica seed extracts against some bacteria. Res Mol Med. 2017; 5(3):32-6. [DOI:10.29252/ rmm.5.3.32]

[17] Nirwana I, Rianti D, Helal Soekartono R, Listyorini RD, Basuki DP. Antibacterial activity of fig leaf (Ficus carica Linn.) extract against Enterococcus faecalis and its cytotoxicity effects on fibroblast cells. Vet World. 2018; 11(3):342-7. [DOI:10.14202/vetworld.2018.342-347] [PMID] [PMCID]

[18] Soni N, Mehta S, Satpathy G, Gupta RK. Estimation of nutritional, phytochemical, antioxidant and antibacterial activity of dried fig (Ficus carica). J Pharmacogn Phytochemistry. 2014; 3(2):158-65.

[19] Al-Qudah MA, Al-Jaber HI, Muhaidat R, Hussein EI, Abdel Hamid AA, Al-Smadi ML, et al. Chemical composition and antimicrobial activity of the essential oil from sinapis alba $\mathrm{L}$. and Sinapis arvensis L. (Brassicaceae) growing wild in Jordan. Res J Pharm Biol Chem Sci. 2011; 2(4):1136-44.

[20] Clinical and Laboratory Standards Institute (CLSI). Abbreviated Identification of Bacteria and Yeast; Approved Guideline. $2^{\text {nd }}$ edition. CLSI document M35-A2. Wayne, PA: Clinical and Laboratory Standards Institute; 2008. https:// clsi.org/standards/products/microbiology/documents/ $\mathrm{m} 35 /$

[21] Mohammadsadegh S, Habibi H, Keshavarzi A, Malekpuor R. Antimicrobial effects of some herbal extracts against infectious bacteria isolated from burn wound. Trends Pharm Sci. 2018; 4(4):219-24.

[22] Cimanga K, Kambu K, Tona L, Apersa , De Bruyne T, Hermans $\mathrm{N}$, et al. Correlation between chemical composition and antibacterial activity of essential oils of some aromatic medicinal plants growing in the Democratic Republic of Congo. J Ethnopharmacol. 2002; 79(2):213-20. [DOI:10.1016/ S0378-8741(01)00384-1]
[23] Warwick SI, Beckie HJ, Thomas AG, Mc Donald T. The biology of Canadian weeds. 8. Sinapis arvensis. L. (updated). Can J Plant Sci. 2000; 80(4):936-61. [DOI:10.4141/P99-139]

[24] Al-Snafi AE. Medical benefit of Lallemantia Iberica: A review. Chem J. 2019; 9:97-102.

[25] Mahboubi M, Feizabadi M, Haghi G, Hosseini H. Antimicrobial activity and chemical composition of essential oil from Oliveria decumbens vent. Iran J Med Aromat Plant. 2008; 24(1):56-65.

[26] Karima S, Faridaa S, Zerroug MM. Antioxidant and antimicrobial activities of plantago major. Int J Pharm Pharm Sci. 2014; 7(5): 58-64.

[27] Al Askari G, Kahouadji A, Khedid K, Ouaffak L, Mousaddak L, Charof $\mathrm{R}$, et al. In vitro antimicrobial activity of aqueous and ethanolic extracts of leaves of Ficus carica collected from five different regions of Morocco. J Mater Environ Sci. 2013; 4(1):33-38.

[28] Jung EK. Antimicrobial activity of extract and fractions from Dryaria fortune against oral bacteria. J Bacteriol Virol. 2007; 37(2):61-8. [DOI:10.4167/jbv.2007.37.2.61]

[29] Sahakyan N, Ginovyan MM, Petrosyan MT, Trchounian AH. Antibacterial and anti-phage activity of Plantago major L. Proceedings of the Yerevan State University. Chem Biol. 2019; 53(1):59-64.

[30] Najafian Y, Hamedi SS, Kaboli Farshchi M, Feyzabadi Z. Plantago major in Traditional Persian medicine and modern phytotherapy: A narrative review. Electron Physician. 2018; 10(2): 6390-9. [DOI:10.19082/6390] [PMID] [PMCID]

[31] Sharifi A, Naghmachi M, Jahedi S, Khosravani SAM. A study on antimicrobial effects of plantago psyllium. Armaghan-e-Danesh. 2010; 16(2):191-9. http://armaghanj.yums. ac.ir/article-1-405-en.html. 